\title{
EDITORIAL CHANGE
}

Readers will have been delighted to hear of the appointment last year of Henrik Ramlau-Hansen as editor of ASTIN Bulletin in succession to Harry Reid. Henrik has subsequently been promoted to the position of chief executive of his company in Denmark and has felt it necessary to step down as editor. We all congratulate Henrik on his promotion and express our regret that he was not able to have a longer term as editor. 